\title{
Financial Prudence through Financial Education: A Conceptual Framework for Financial Inclusion
}

\author{
Laily Dwi Arsyianti \\ Lecturer at Bogor Agricultural University, Indonesia \\ Salina Kassim \\ Associate Professor, Institute of Islamic Banking and Finance (IIiBF), \\ International Islamic University, Malaysia
}

\begin{abstract}
This paper aims to develop a framework to improve financial prudence through financial education and financial inclusion for low-income households in Indonesia. Knowledge shapes attitude, which later influences behavior. A household, in terms of its social production function, needs to feel secure financially in order not to fall into insolvency or bankruptcy. Households that are equipped with better financial education and knowledge are more likely to undertake recommended financial behaviors. By targeting the low-income group through a financial inclusion agenda, the government, Islamic social finance practitioners, and academicians enable low-income households to act with financial prudence.
\end{abstract}

Keywords: financial behavior, financial inclusion, financial education, low-income households.

KAUJIE Classification: E31, G5, Q73, S7.

\section{Introduction}

A financial inclusion agenda is aimed to improve people's ability to deal with risk, to manage money (funds) for future consumption, and later to gain more money by investing, thus benefiting both the owner of funds and society overall (Driver, 2015). It ensures that a financially excluded customer has affordable, transparent, and regulated access to formal financial institutions rather than existing informal alternatives (Bank Indonesia, 2015).
Financial inclusion has become a trend after the financial crisis in 2008. It mainly serves the bottom of the population pyramid which includes people with low income, those who live in remote areas, disabled people, undocumented labor, and rural people (Bank Indonesia, 2015). The G20 summit in 2010 pledged support for financial inclusion to reduce poverty in the world. The Association of South East Asian Nations (ASEAN) has also integrated this 
program into its 2015 Economic Community Blueprint. The United Nations have translated the poverty eradication agenda into the eighth Millennium Development Goals in 2000. Poverty has been reduced by a half in 2010, and by 2015 poverty has declined by more than half (United Nations, 2015). Even though financial inclusion has more than doubled in most developing countries as reported by the World Bank (2014), it still requires some work.

As a developing country, Indonesia has implemented a triple-track strategy comprising pro-growth, pro-jobs and pro-poor policies in 2004, with proenvironment adopted and added in 2007 (Dhewanthi, 2012 , p. 2). Development encourages growth of the economy while creating more employment, especially for the population at the bottom of the pyramid. A development program should prevent any destructtion to the environment, nature, as well as society. Although the government has this spirit, technology, skills and infrastructure still remain a constraint (Tambunan, 2015, p. 11). Among the poorest $40 \%$ in Indonesia, $78 \%$ of adults are still unable to open a bank account (Kendall \& Klapper, 2015). In other words, only $22 \%$ of the population has a bank account. In terms of lending access, a major contribution to the problem is caused by the wider pool of lowerstandard (also known as sub-prime) borrowers (Morgan \& Pontines, 2014, p. 6). Their low standard indicates a high risk of defaulting. Besides, from a regulator point of view, not-properly-regulated microfinance institutions may dilute the overall economy. Work needs to be done on two fronts. From the borrower point of view, financial education is needed to improve their ability in managing money. From the financial institution or regulator point of view, proper regulation of provider institutions is highly needed.

Therefore, this paper aims to develop a framework for a financial inclusion agenda in Indonesia. The goal of our proposed financial inclusion strategy is to provide the Islamic social finance institutions and academicians with a deeper knowledge regarding financial inclusion.

\section{Literature Review}

According to the World Bank, financial inclusion is a key enabler for alleviating poverty and boosting prosperity (World Bank, 2016a). A structured consul- tation can help ensure success for a national strategy on financial inclusion (World Bank, 2016b). By 2020 , the whole of the adult population is targeted to perform financial transactions through bank accounts or electronic instruments for savings, and transferring and receiving payments (World Bank, 2016c). From the government's perspective, the outcome of a financial inclusion strategy is to help those with low income and initially excluded from formal financial institutions to achieve manageable financial living.

From an Islamic perspective, as narrated by alTirmidhi in a hadìth $(2007$, vol. 4, p. 373 , hadìth no. 2344), a bird flying in the morning with an empty stomach and going back with a full stomach is described as manageable living. Furthermore, one should have a work ethic and obey Islamic rules (Qur'ān, $9: 105 ; 67: 15)$, or otherwise, instead of receiving blessings, one will suffer from calamities (Qur'ān, 7:95-96). One of the calamities is suffering from heavy debt, as narrated by al-Bukhari in a hadith (1997, vol. 8, p. 210, hadìth no. 6369).

To free oneself from financial difficulties (and if one is a true believer), charity is one of the solutions, as Allah will reward them from sources he/she could never imagine (Qur'ān, 65:2-3). Charity-giving is recommended for not only those who are in prosperity but also for those who are in affliction (Qur'ān, 3:134). As mentioned by al-Qurtubi (1993, vol. 2, p. 132), 'in prosperity' means being rich, in comfort, and happy. Similarly, affliction is defined as being poor, in difficulty, and inconvenience. Allah has also stressed upon believers to give charity before the end of their life because those who never paid charity will regret it and request Allah to postpone their death so that they can give charity (Qur'ân, 63:10). Irrespective of a man's economic condition, whether he is in richness or in poverty, charity-giving is important and urgent in human life.

On the other hand, the reward for charity-giving will be as much as 700 times (Qur'ān, 2:261). Giving charity is also described in the Qur'ān (35:29-30) as trading that would have never incurred any losses. Prophet Muhammad (may Allah's peace and blessings be upon him) also stated that among the best charities is when one expects survival and fears poverty (Abu Dawud, 2008, vol. 3, p. 414, hadìth no. 2865). Combining those verses and hadith, it can be 
concluded that charity-giving can be the way to overcome indebtedness and other life difficulties faced by mankind. Poverty will not refrain a poor person from charity-giving. On the basis of this concept, the Indonesia National Board of Zakat (Badan Amil Zakat Nasional, BAZNAS) has included charity-giving as part of the zakāh-based empowerment program of the poor and the needy. The recipients of zakäh are taught to have a charity commitment as the way to enhance their life conditions and change their mentality from being the receiver to becoming the giver. Besides, they are also encouraged to be more productive.

Siegwart Lindenberg introduced the Social Production Function (SPF) theory (Lindenberg, 1996; Ormel, Lindenberg, Steverink, \& Verbrugge, 1999), which integrates both psychological and economic theories of consumer/household production. The word production here is taken to mean as that described by Becker (1976). He introduced a household production function when a household takes more production than consumption activities. The household is considered an organizational entity, which is like a corporate. Households invest their resources into capital assets (e.g., savings), capital equipment, and human capital. Thus, it deals with labor and capital in the same way a firm does. SPF eliminates the priority of satisfaction that is a trade-off with various needs. Furthermore, it proposes two optimum goals of humans, namely physical well-being and social well-being.

Physical well-being can be subjective (self-report on physical symptoms) or objective (physical indices) (McKee-Ryan, Song, Wanberg, \& Kinicki, 2005 , p. 54). It integrates the theory of arousal where one may have a higher arousal when the stimulus increases and less arousal when one experiences comfort (Lindenberg, 1996, p. 173). For example, an investor's arousal might increase once he/she finds a new potential investment in a new field. On the other hand, a risk-averse investor might feel comfort while receiving regular revenues within a period and refuses to search for other investment products. Thus, stimulus in Lindenberg's concept is the same as subjective well-being in the McKee-Ryan et al. study.

The concept of "going concern" is also introduced in this theory. It presumes that households need to feel secure financially in order not to fall into insolvency (failing to pay back the debt) or bankruptcy (fair market value of assets less than liabilities). Households rely on internal financing, which depends on their net worth through accumulation of personal income. When households cannot fulfill their needs through their net worth, they will find external sources to fund their needs (Belsky \& Calder, 2005, pp. 32-37).

Basic needs as stated in the Qur'ān comprise the need to perform worship; the need for food, clothes and housing; and the need to feel secure and safe (Qur'ān, 20:118-120; 106: 3-4). These needs are divided into material and spiritual needs. Inability to fulfill these needs will lead a person or a household to be considered as materially poor, spiritually poor, or both (Beik \& Arsyianti, 2016, pp. 144-148). However, to fulfill these needs and with regard to insolvency, a Muslim should view debt as the last resort because of the consequences that can be incurred (Obaidullah, 2008, p. 17). First, one who borrows should have a strong intention to pay back. Prophet Muhammad (may Allah's peace and blessings be upon him) stated that a debtor can pay back his/her debt if he/she has a strong intention to pay it back (alBukhari, 1997, vol. 3, p. 328, hadith no. 2387). Even a small amount of debt is hard to pay back if one does not have any intention of paying it back. Conversely, a big amount of debt would be paid back easily if one has a strong intention to pay it back. Secondly, the debt amount should be in the range of one's capability of paying back (Beik \& Arsyianti, 2016). The indicator of the range can be one's income, receivables, or deposits. Therefore, a Muslim should not simply take debt without considering these two points.

DeVaney (1994) studied financial ratios as predictors of household insolvency in the United States. By using Survey of Consumer Finance data of 1983 and 1986 and utilizing a logistic regression method and classification tree procedure, it was found that liquidity, asset-to-liability ratio, and debt payment over disposable income (debt service) ratios appeared to be the most useful indicators to predict insolvency of households.

The concept of comfort in the SPF theory was studied under subjective well-being in the McKee- 
Ryan et al. study in which they integrated psychological and physical well-being. The assessments of this outcome are hard to understand by observing, but it can be understood by asking the individual personally. However, diminishing returns were applied in this case, as an individual had more physical wellbeing, additional stimulation and less comfort (Ormel et al., 1999).

In terms of social well-being, this depends on status, behavioral confirmation, and affection. Commenting on this, Lindenberg argued that individuals might sacrifice themselves and feel embarrassed after doing something good for others. However, in society this person is praised even though he/she felt embarrassed according to his/her perspective. Instead of being humiliated by his/her situation, he/she gets the status, behavior confirmation, and affection in society. Thus, self-esteem is not the ultimate goal of an individual. Self-seeking concepts that produce good outcomes for society is not necessarily applied in the family and neighborhood concept (Veenhoven, 1999). In fact, personal financial behavior affects family life and workplace (Garman, Leech, \& Grable, 1996). With regard to lifestyle, it is empirically shown that richer countries exhibit a lower correlation between individual behavior and society or his/ her surroundings (Ormel et al., 1999). Prophet Muhammad (may Allah's peace and blessings be upon him) stated that one Muslim to another is like a body; if one part of it gets sick, the rest of them feel the sickness (al-Bukhari, 1997, vol. 8, p. 210, hadìth no. 6011). One could not be considered a Muslim if he/she does not love other Muslims like how he/she loves him/herself. For instance, when someone suffers from sickness, it is almost impossible for him/her to solve everything by himself/herself. It is the concept of brotherhood that a society needs.

In the British Household Panel Survey, 5,500 households were observed and analyzed by utilizing autoregressive distributed lag and fixed effects models (Winters \& Rundlett, 2015). It was found that participation in social life would bring happiness and satisfaction in life. In another study by de Oliveira, Eckel, and Croson (2012) in Dallas, the participants were asked to give a series of donations for local charitable events. After the experiment, they were given a questionnaire to be answered. The results show that making a contribution in the public inte- rest appeared to be a stable preference. Participants felt they had done "the right thing" based on a religious perspective.

\section{Financial Behavior of Low-Income Households}

Individuals need to show appropriate behaviors related to cash management, credit and debt management, and planning for various life-cycle events such as marriage, education, retirement, estate planning, and consumerism (Joo, 2008, p. 31). Individuals' attitude towards personal financial wellbeing is one subjective perception that can lead to appropriate behavior. Financial knowledge is also a significant component of subjective perception. In the marketing theory of knowledge-attitude-behavior model, financial knowledge can influence financial attitudes and lead to better financial behavior and thus improved financial wellbeing.

One theory that explains the behavior of humans is the theory of planned behavior (TPB). TPB was developed by Ajzen (1991). TPB framework predicts and understands human behaviors. TPB is an extension of the theory of reasoned action (TRA) (Ajzen, 1991, p. 199). TRA was introduced by Fishbein in 1967. According to TRA, the behavior of an individual is determined by his/her intention in performing a particular behavior. The intention is determined by attitude toward the behavior, the subjective norm, and the relative importance between the attitude and the subjective norm (Xiao \& Wu, 2008, p. 73). Later, the theory was developed and perceived control was added to the model to determine the behavior intention. According to this theory, behavioral intentions are influenced by attitudes, subjective norms, and perceived behavioral controls. In turn, behavioral intention influence one's behavior achievement (Ajzen, 1991, p. 184).

Ajzen and Fishbein (1980) imply that behavior itself is not an outcome since it only contributes partly to the outcomes. Outcomes result from both one's own behavior and other possible factors in many situations. Other factors remaining stable, debttaking consecutively might lead to bad liability performance and an increased debt service ratio.

They also remark that behaviors can be observed by indicators of single acts or behavioral categories. A single act is a specific behavior that an individual 
performs. Taking debt for long-term consumption is an example of a single action. Many financial behaviors are defined by sets of single acts. For example, cash management is still an abstract behavior that needs to be described by a set of single acts, such as reviewing monthly bills and recording monthly expenses. Once an abstract behavior is defined, the reliability assessment is more important since single acts may or may not contribute to the target behavior category. For example, taking debt for long-term consumption may represent a house-hold's cash management behavior or just demonstrate the household's habit that is not related to cash management.

Furthermore, they also state that behavior should be defined appropriately and should have four essential elements: action, target, context, and time. For example, debt-taking behavior (a behavioral category) can be a short-term or one-time action, such as taking a small amount of debt from relatives, or a long-term action, such as consecutively taking debts after repaying the former. Also, debt can be taken from relatives or financial institutions (targets). Debttaking behavior can be regular or occasional (times).

First, behavior can be measured as a binary variable, whether or not to perform the behavior. Second, it can be measured through multiple choices. The third is quantifying the extent to which the behavior has been performed, for example, the limit of debttaking amount. The fourth approach is to measure the frequency of performing the behavior, for example, once during an emergency or consecutively thrice a year.

If the purpose is to encourage low-income households to participate in charity-giving, a binary variable, to participate or not, will be adequate. However, if the research question is to encourage the household to increase charity-giving, a multiple choice set with a range of contributions or an actual contribution amount is required.

An evaluation study examining 185 independent studies toward the TPB showed that in general, the theory is valid (Armitage \& Conner, 2001, p. 489). This evaluation research addressed several issues relevant to the application of the theory. First, selfreports are not a reliable information source. Resear- chers should use objective and observed variables to measure behavior. Thus, quantitative research design is appropriate. Second, perceived behavior control (PBC) and self-efficacy are the same measure with two different names. Compared to PBC, self-efficacy is a better predictor of behavior. $\mathrm{PBC}$ reflects more on external factors; it is better used for exercised behaviors. Third, there are alternative measures for intention, e.g., desire and self-prediction are better predicttors of behavior compared to desire. Fourth, subjective norm (SN) is a weak predictor of intention compared to the two other variables, attitude and perceived control. As shown in pilot research, when $\mathrm{SN}$ was included in the analysis, the model did not have a good fit. Alternative indicators may be needed, such as moral and descriptive norms.

Factors affecting consumer behavior in conducting debt management plans have been examined by Xiao and $\mathrm{Wu}$ (2008). They found that attitudes toward behavior and PBC affected actual behavior, but subjective norm did not. In addition, they found that satisfaction with the service also contributed to actual behavior. Meanwhile, demo-graphic factors did not affect actual behavior directly but indirectly through attitude, perceived behavior control, and subjective norms.

Attitude, perceived behavior control, and subjecttive norms influence specific behavior through intention. Intention reflects the motivation of an individual to perform a specific behavior. It measures how strong the motivation is as well as how much effort an individual makes to perform such behavior. Attitude, perceived behavior, and subjective norm independently prompt influence (Ajzen, 1991, pp. 188-189).

Thus, in accordance with the outcomes, specific behaviors of low-income households include consecutively taking debt and regularly giving to charity. Consecutively taking debt can influence insolvency of a household. Meanwhile, regular charity-giving can influence social well-being as elaborated in SPF theory. Arsyianti and Kassim (2016, p. 149) found that the debt service ratio is correlated with regular charity-giving behavior; on the other hand, Arsyianti and Beik $(2015$, p. 86$)$ found that charity per income is not significantly correlated with debt service ratios. 


\subsection{Attitude, Perceived Behavior Control, and Subjective Norm}

Attitude reflects one's reaction, evaluation, or appraisal, favorably or unfavorably, towards a specific behavior. Those attributes are derived from cognitive knowledge. Thus, attitude is developed from people's belief upon one particular object associated with a certain attitude (and relatively with other attitudes) (Ajzen, 1991, pp. 189-192).

Subjective norms reveal the state of approval or disapproval by significant other parties. Reference people are believed to affect one's specific behavior. These important others comprise those who are believed to being relatively close to the one who performs the specific behavior. They may be friends, spouse, siblings, or other family members, parents, or even neighbors. In a specific context, the salient referents in conducting leisure activities, according to Ajzen (1991, p. 195), are friends, parents, spouse, siblings, and other family members.

In the event that a person has a favorable attitude towards a specific behavior and believes that important others approve of such behavior but still does not exhibit a strong behavior, he/she may believe that he/ she has no resources or opportunity to perform that behavior. Thus, he/she needs an adequate conscious decision to carry out the behavior based on past experience (Abduh, Duasa, \& Omar, 2011, p. 217). Experiences of an individual in the past or acquaintances or other people, or second-hand information gathered by an individual associated with a specific behavior, increases or decreases the performance of that individual to accomplish a specific behavior (Ajzen, 1991, p. 196).

Factors mentioned above are known as behavior beliefs which influence one's attitude toward behaveior; normative beliefs which form subjective norms, and control beliefs which mean perceived volition, control influences in executing that behavior. In some cases, the intention to perform behavior may only be influenced by two factors, which are attitude and perceived volition control, while in other cases all three factors may affect the intention (Ajzen, 2002, p. 672).

A study by Bekkers and Wiepking (2011) elaborated the reasons behind charity. They looked at this from a multidisciplinary perspective covering marke- ting, economics, social psychology, biological psychology, neurology, sociology, political science, anthropology, biology, and evolutionary psychology. Eight indicators were identified as the reasons for someone to give to charity. They were: aware of the needs, solicitation, physical costs and benefits, altruism, reputation, psychological benefits, values, and efficacy.

\subsection{Socio-economic Demography}

Even though demographic factors do not directly influence behavior, and thus are excluded in the TPB model, these factors significantly affect behavior in order to achieve the outcomes in many studies related to financial behavior (Sahi, 2013; Stone \& Maury, 2006; Mewse, Lea, \& Wrapson, 2010; Lusardi, 2008; Lea, Webley, \& Walker, 1995; Livingstone \& Lunt, 1992; McKee-Ryan et al., 2005; Xiao \& Yao, 2014; Schlegelmilch, Love, \& Diamantopoulos, 1997; Hogarth, 2006; Hilgert \& Hogarth, 2003; Lyons, Chang, \& Scherpf, 2006; Garman, Kim, Kratzer, Brunson, \& Joo, 1999; Havens, O'Herlihy, \& Schervish, 2006; Plagnol, 2011). The demographic factors that influence behaviors are: level of education, age, marital status, family size, employment, origins, charity per in-come, income, future expectations, religious factors, gender, financial institutions, home ownership, and financial education. For example, Wright (2001, pp. 405-413) found that the origin of donors affected their method of giving.

\section{Low-Income Households and Financial Education}

To protect consumers and society in general, the Indonesian Financial Services Authority (Otoritas Jasa Keuangan, OJK), through the OJK Act No. 21 (2011), stated that the consumer and society should be given information and education regarding financial services characteristics, its products, and facilities. This role highlights the OJK's position as a regulator and organizer of the financial system in Indonesia while protecting the right of the society, especially customers and users of the products and services of financial institutions. This objective is also stated in the six pillars of Indonesia Economy Architecture (Bank Indonesia, 2008).

Low-income micro-entrepreneurs have very limited access to working capital financing/credit. This is 
attributed to various reasons including lack of experience, low education levels, and low credit balances, resulting in substantial constraints for them in getting access to credit. These reasons also apply for the credit balance situation (Zhu \& Meeks, 1994, pp. 415-418). The various forms of credit constraints are challenges to the financial inclusion effort which promotes the idea that access to credit is the right of human beings. A supporting system to this concept has tremendously developed. However, as the access to credit for this population rose, the risk of overindebtedness has been repeatedly highlighted. Amidst these issues, the idea of financial inclusion is very much doubted (Hudon, 2009, p. 3).

During the Ottoman reign, 1500-1914, credit did not get support to be expanded. Formal banking institutions were absent in the Ottoman society (Pamuk, 2004a, p. 11; Pamuk, 2004b, p. 232). Islamic prohibition on usury and interest prevented them from developing this product. However, courts recorded cases involving debts. Mostly, the cases were dealing with family members borrowing from or lending to other family members, and not limited to informal external sources. All cases involved whole society segments, urban or rural.

Today, accessibility to formal financial institutions is highly relevant in the context of Indonesia because of a large proportion of low-income people, ill-informed on financial matters at the bottom of the economic pyramid. This situation should be addressed and repeatedly informed to the target population, namely that low-income individuals and households should be the recipients of carefully designed financial education programs. Continuous technical suport, mentoring, counseling, and monitoring are highly needed to establish a productive, successful, and fruitful poverty alleviation agenda through financial assistance programs. Thus, financial education is essential, particularly to low-income families, to enable them to manage their day-to-day financial resources and avoid landing into financial difficulties.

Financial education can be a highly effective method to improve financial literacy among society (Hogarth, Beverly, \& Hilgert, 2003). Financial literacy is basically the possession of basic knowledge about how to earn money, manage various unexpected future events, and disburse it to help others (Giesler \& Veresiu, 2014). It is also important to know how to properly utilize spending according to budgetary constraints. Financial education is one piece of the puzzle to achieve financial literary among consumers. Hogarth (2006, p. 7) mentioned that disclosures and information, substantive protections, and professional advice are some pieces to complete the puzzle. This is because being financially literate is being knowledgeable, educated, and informed regarding managing money and assets, which comprises planning, implementing, and evaluating financial decisions (Mccormick, 2009, p. 71).

Through improved financial literacy, one is hoped to be better able to use resources, increase economic security, improve the contribution to the community, and finally build a thriving community and welleducated labor force (Hogarth, 2006, p. 12). This is simply because there is a correlation between knowledge and behavior wherein those with better financial education and knowledge are more likely to undertake recommended financial behavior (Hilgert \& Hogarth, 2003).

Therefore, priority audiences of financial education need to be properly identified and targeted, which include youngsters (Mccormick, 2009, pp. 72-73; Mandell \& Klein, 2009, pp. 16-17) and first-time homebuyers (Hogarth, 2006; Hilgert \& Hogarth, 2003; Hogarth et al., 2003). Another targeted group is the low-income households. Financial education has been proven to improve financial knowledge (Zhan, Anderson, \& Scott, 2006; Muflihani, 2015, pp. 9-27; Martin, 2007, pp. 19-22), improve skills (Muflihani, 2015 , p. 18), and change financial behavior effectively (Lyons et al., 2006, p. 41) among low income populations in many countries.

Financial education in the workplace has been proven to be effective in increasing employees' welfare (Garman et al., 1999). Most programs to improve employees' financial well-being are dedicated to preparing them for their retirement. Being able to make financial decisions with confidence is one of the indicators to assess employees' financial wellbeing.

To attain better outcomes in the form of behavior change toward better financial discipline, especially in terms of creditworthiness, the following steps are suggested as depicted in Figure 1. 


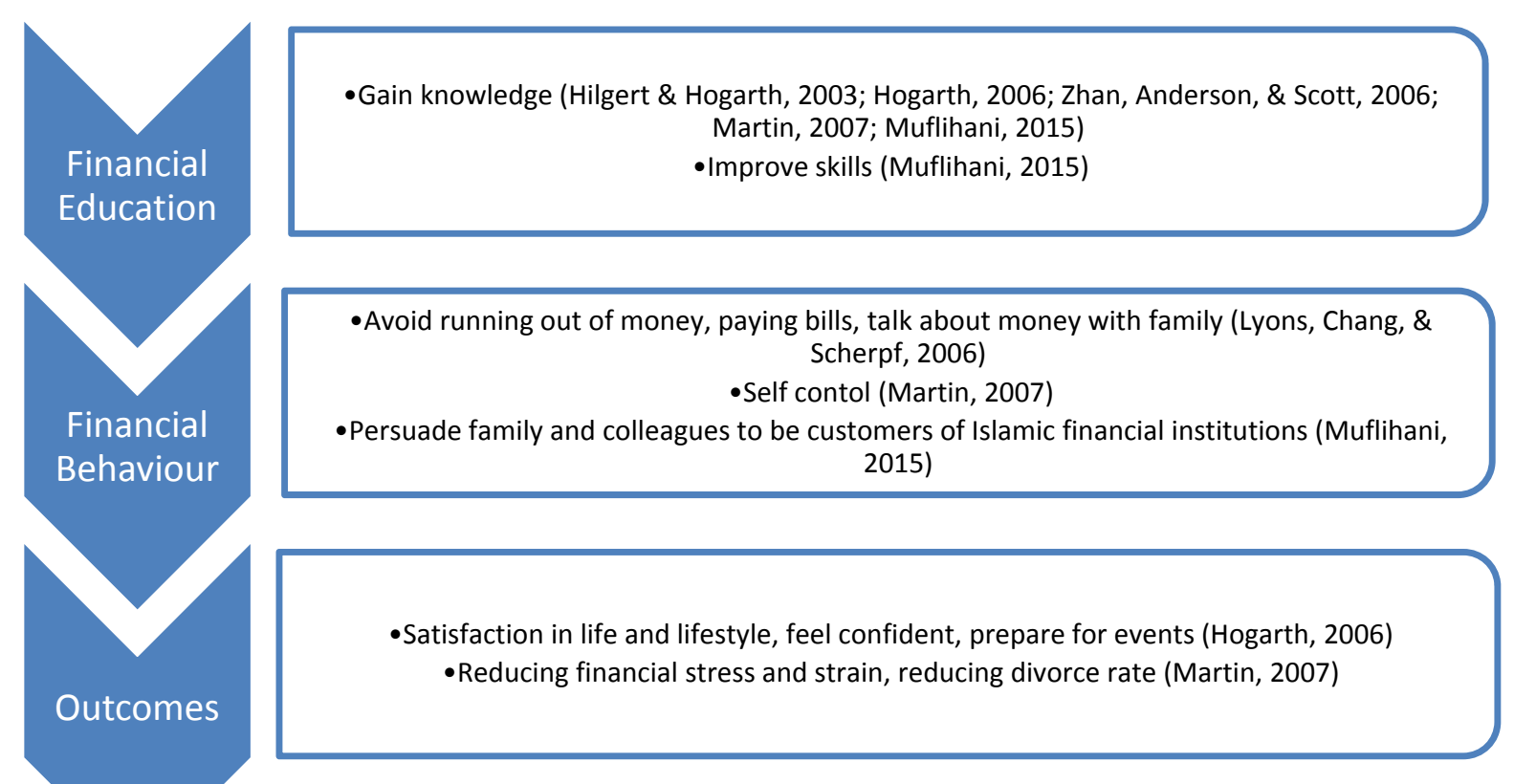

Figure (1) Outcome of Financial Education

Toward the end of financial education, the lowincome population is expected to perform improved financial behaviors. Contributing to society is also an indicator that improves, as enhanced financial wellbeing boosts personal satisfaction and this feeds through into social wellbeing (Hafidhuddin, 2007, p. 60).

\subsection{Financial Education through Financial Institutions}

Low-income households are closer to microfinance institutions (MFI) than social finance institutions. Microfinance institutions grow fast in rural areas instead of in big cities. On the other hand, social finance institutions grow in larger cities since their stakeholders, the source of funds, are mainly located in urban areas. Consumers in Indonesia have access to a wide range of financial service providers such as banks, insurance companies, investment companies, pawn broking firms, leasing companies, securities compa-ies, and many MFIs (including bayt al-māl wa tamwìl, $\mathrm{BMT}^{(1)}$ ), cooperatives, and also loan sharks $^{(2)}$. There are 106 conventional commercial

(1) BMT is an Islamic microfinance institution in Indonesia. It provides charity-based as well as for-profit financing.

(2) A loan shark is an informal money lender who charges a very high interest rate to the debtor and employs debt collectors to collect the money. In the case of Indonesia, the money is collected on a daily or weekly basis. If the debtor fails to pay, the loan shark will charge a multiplied amount, thus the interest rate becomes higher. banks, 12 Islamic banks, and 5,023 rural banks. These institutions collect funds from society and invest in the form of financial products, for example, credit, securities, and other productive assets. Banks and non-bank financial institutions are all defined as financial institutions (OJK, 2015). Meanwhile, nonbank financial institutions collect funds directly or indirectly from society by issuing securities and use them to finance a company's investment, either as a credit/loan or as additional capital.

Since many financial institutions provide financial services to society, individuals, as well as households, are forced to decide wisely. In order to make good decisions, consumers should have sufficient knowledge to efficiently utilize products and facilities offered by financial institutions. The Organisation for Economic Co-operation and Development (OECD) has pointed out the need to improve financial literacy through financial education (OECD, 2006).

Three out of nine principles of financial education and awareness have mentioned the role of financial institutions. However, financial institutions, at the very beginning of their commencement, aim to earn as much profit as possible. Even the MFIs charge a higher rate of interest compared to commercial financial institutions (Yumna \& Clarke, 2011, p. 6). They argue that they need to cover high operational costs. 
Even though Muslim consumers have been offered support by Islamic financial institutions (IFIs), it seems that the IFIs fail to attract this population. In fact, IFIs charge a higher rate than conventional counterparts because the operational overheads are relatively high (Beik \& Arsyianti, 2008, pp. 27-28). Thus, the idea of overcoming poverty in Indonesia through IFIs may seem impossible since the cost is still the constraint in attempting to impart financial prudence through financial education (Willis, 2011).

A customer service desk may be an effective way to educate customers in person. However, this may consume more time for customers to be served and educated on the spot. Thus, mass media is still the effective way to educate customers (Muflihani, 2015, p. 24; Hogarth, 2006, p. 18).

Another way is through seminars and public talks as many people can be gathered in one place at one time. Financial institutions can collaborate with OJK and/or universities to organize seminars or talks. As explicitly stated in the OJK Act, OJK must have programs correlating with financial education. Universities have ample and credible human resources that can help the programs to be realized. Students' organizations can also be active agents for organizing this kind of event.

These programs, however, are specifically made for those who have easy access to formal financial institutions. What about the poor and low-income households that have limited access to formal financial institutions? We discuss this in the following section.

\subsection{Financial Education through Social Finance Institutions: Serving the Consumers at the Bottom of the Pyramid}

In the Islamic financial system, there are several social finance institutions that could play a role in educating consumers at the bottom of the pyramid, apart from their normal functions of collecting and distributing charity, endowment, or other free money. Specifically, Waqf (Endowment Fund) Act 41 (2004) and Zakat (Compulsory Donation) Management Act 23 (2011) (replacing Act 38 of 1999) provide the solution to this issue. Waqf and zakāh institutions have played a major role in social finance. Both directly deal with the donors as well as ultimate recipients. The majority of the recipients or the ultimate users that highly utilize the funds in Indonesia are categorized as poor and low-income households (Yayasan Dompet Dhuafa Republika, 2013; BAZNAS, 2015). Unlike financial institutions, social finance institutions are rather keen to disburse the collected funds without aiming for any profit motive.

According to the Zakat Management Act, as an 'āmil (institution collecting and distributing zakāh funds), BAZNAS and private zakāh institutions (Lembaga Amil Zakat, LAZ) are able to collect zakāh as well as other social funds. Zakāh is a compulsory mandate, while waqf (endowment fund) results in stable and permanent expected benefit (Obaidullah, 2008, pp. 31-36). Both are sadaqah (charity) in Islam, while another type, infāq (monetary charity), is voluntary and may be discharged according to the mandate (Yumna \& Clarke, 2009, p. 4). Thus, infāq can be used for any purposes and not limited to the mustahiqq (deserving beneficiaries) group.

Islamic social finance institutions have more options to finance their program compared to other financial institutions. First of all, they are the ones who directly and regularly keep in touch with the poor and low-income households and individuals. Understanding the situations facing the poor thus enables them to effectively educate the poor and lowincome households and individuals. In an annual report of social finance institutions in Indonesia, it is said that the poor is still the main targeted group to disburse the collected funds (Yayasan Dompet Dhuafa Republika, 2013; BAZNAS, 2015).

Secondly, in-line with government's efforts to alleviate poverty in Indonesia, relevant authoritative bodies can collaborate with the OJK, including the Social Ministry, as well as the Ministry of Religious Affairs. As stated in the Zakat Management Act, operations of BAZNAS can be financed from the state budget (Anggaran Pendapatan dan Belanja Negara, APBN) as well as from the right of the 'amil fund (considered an operational cost of 'amil). A similar situation also prevails in the Indonesia Board of Waqf (Badan Wakaf Indonesia, BWI), wherein it is stated in the Waqf Act that the government should support BWI financially. OJK can provide the materials and human resources. Meanwhile, along with the Social Ministry and Ministry of Religious Affairs, social finance institutions may integrate their programs. Thus, there will be no overlapping events. 
Thirdly, social finance institutions operations are also in-line with society's desire to provide a better financial life. Zakat Management Act has put social contributions in explicit terms. Para 35 in this Act states specifically how society can contribute. Social finance institutions in Indonesia can encourage muzakkī (zakāh payer) or munfiq (infāq donator) or wäqif (waqf donator) to actively share their knowledge, build recipients' skill to utilize financial facilities, and build their trust to control potential financial problems.

Moreover, the free money that is collected by the social finance institutions can be distributed without a burden to get more and more profit. The performance of these institutions is not assessed by its profit; they would rather be assessed by their activities in collecting and distributing funds and effectiveness in contributing to society.

In influencing positive financial behavior through financial education, Lee and Miller (2012) propose social marketing as the method that can be used by social organizations to promote specific behavior. They present seven strategies as the best practice in several countries. First, the purpose and focus should be agreed upon. A behavior change program should set a specific mission within a specific period and should be determined in advance. For instance, an 'amil institution set a financial training program to empower all mustahiqqs, be familiar with Islamic financial transactions, and transform at least half of them into muzakkis within two years. This goal is then to guide an 'ammil institution to focus on setting financial education for the mustahiqqs.

Second, the target audience should be identified and described. Who is the target audience for the program? Is it appropriate for young audience, or should it be appropriate for the aged instead? On the other hand, a question like "what is the appropriate financial education program for working mothers?" may appear because the audience is ready to join a financial education program but the program has not been established yet. Such questions should be answered meticulously. The recommended strategy should be examined for a particular situation: targeting particular audiences for a program that has already been settled, or setting a program for a particular audience that demands financial education.
Third, specific behavior should be selected. Another strategy is aiming a specific behavior that should be achieved by the target audience after joining a financial education program. For example, a financial education organization is targeting the audience to be more aware and disciplined in repaying debt because perhaps a non-performing financing rate is increasing in a particular area. Thus, the most recommended strategy for financial education is setting a specifically targeted behavior.

Fourth, audience barriers are understood and addressed. In promoting Islamic financial products and services, the IFIs may find that their customers consider their products to be similar to their conventional counterparts. This issue should be identified and addressed through financial education. Thus, such a financial education strategy is recommended in targeting customers for IFIs.

Fifth, the program should consider the 4Ps (product, price, place, promotion). When a program organizer faces difficulties in executing the idea, considering the 4Ps may be the most recommended strategy.

Sixth, partnerships should be formed. Some financial education programs may have been established and well-planned. However, the programs may need to be executed by appropriate partners. For example, who will be appropriate in educating people to give to charity more regularly? Or who will educate people in choosing the most appropriate financial product for a particular transaction? The strategy of choosing appropriate partners should be recommended for such a situation.

Lastly, evaluation should be conducted and reported. When outcomes mostly fail to be achieved, the financial educator should be more aware in evaluating the programs. In this sense, being more responsive to program evaluation may be the most recommended strategy.

These strategies are not necessarily discussed in a specific order. Instead, while executing financial education all circumstances should be considered before choosing the most recommended strategy. Every condition has its own issue and may differ from one area to another, one country to another or one institution to another. Therefore, financial education should be planned based on the most appropriate strategy in a particular condition. 
According to the above literature reviews, the framework for a financial inclusion agenda to impart financial education to low-income households is shown in Figure 2.

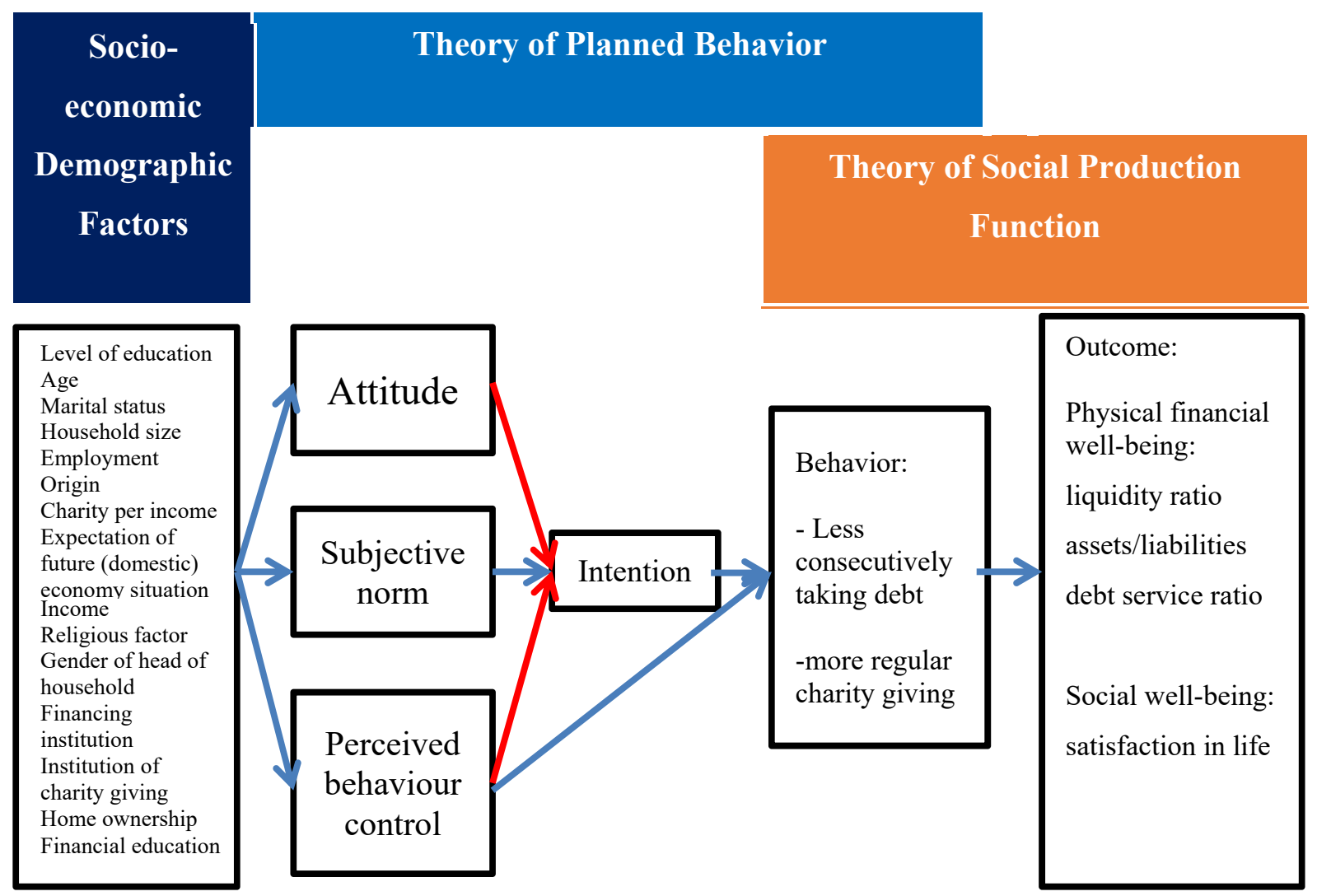

Figure (2) Conceptual Framework for Instilling Financial Prudence to Low-Income Households

\section{Conclusion}

Financial literacy is about not only gaining knowledge through financial education but also displaying better financial behaviors. SPF theory and the theory of planned behavior have been elaborated to highlight the objectives of this paper. Eventually, the process is hoped to produce the expected outcomes.

This conceptual framework is important since it will involve various stakeholders, especially government as regulator and social finance institutions as executor. If government wants to win low-income consumers in a financial inclusion agenda, further studies need to be done into what low-income households' current financial knowledge and financial behavior is, and what steps low-income consumers should take to succeed in their financial life. Sharing information on programs and experiences at an international level to promote financial service accessibility and financial management can be helpful. More attempts to develop these programs would be helpful. Thus, social finance institutions should play an increasing role to support the government's agenda of financial inclusion through financial education for low-income populations. 


\section{References}

Abduh, M., Duasa, J., \& Omar, M. A. (2011). Factors Influence Depositors' Withdrawal Behavior in Islamic Banks: A Theory of Reasoned Action. World Academy of Science, Engineering and Technology, 60, 216-221.

Abu Dawud, Sulaiman bin Ash'ath (2008). English Translation of Sunan Abu Dawud. Riyadh, KSA: Darussalam.

Ajzen, I. (1991). The theory of planned behavior. Organizational Behavior and Human Decision Processes, 50(2), 179-211.

Ajzen, I. (2002). Perceived Behavioral Control, SelfEfficacy, Locus of Control, and the Theory of Planned Behavior. Journal of Applied Social Psychology, 32(4), 665-683.

Ajzen, I., \& Fishbein, M. (1980). Understanding attitudes and predicting social behavior. Englewood Cliffs, NJ: Prentice-Hall.

Armitage, C. J., \& Conner, M. (2001). Efficacy of the Theory of Planned Behavior: a meta-analytic review. British Journal of Social Psychology, 40(4), 471-499.

Arsyianti, L. D., \& Beik, I. S. (2015). Debt Service of Low-Income Households in Indonesia. Jurnal AlMuzara'ah, 3(1), 76-88.

Arsyianti, L. D., \& Kassim, S. (2016). Regular charity giving of low-income households in Indonesia. Intellectual Discourse, 24(1), 133-156.

Badan Amil Zakat Nasional. (2015). Penerimaan dan Penyaluran Tahun 2015, Bulan Juni 2015 (Collection and Distribution in 2015, June 2015). Retrieved from: http:/pusat.baznas.go.id/wp-content/uploads/down loads/2015/08/Laporan Keuangan Bulanan Baznas Juni 2015.pdf

Bank Indonesia. (2008). Enam Pilar API (Six Pillars of API). In Arsitktur Perbankan Indonesia (Indonesia Banking Architecture) (pp. 6-7). Retrieved from: http:/www.bi.go.id/id/publikasi/perbankan-danstabilitas/arsitektur/Documents/838faflb782a4679bdd7 0fd1f5b1dbd4enam_pilar.pdf

Bank Indonesia. (2015). Keuangan Inklusif (Inclusive Finance). Retrieved on October 21st, 2015, from: http://www.bi.go.id/id/perbankan/keuanganinklusif/Ind onesia/Contents/Default.aspx

Becker, G. S. (1976). Economic Approach to Human Behavior. Chicago: University of Chicago Press.

Beik, I. S., \& Arsyianti, L. D. (2008). Why the rate of financing in Islamic Banks is High? An Analysis Based on Malaysia Case. TAZKIA: Islamic Finance \& Business Review, 3(1), 18-29.
Beik, I. S., \& Arsyianti, L. D. (2015). Construction of CIBEST Model as Measurement of Poverty and Welfare Indices from Islamic Perspective. Al-Iqtishad: Journal of Islamic Economics, 7(1), 87-104.

Beik, I. S., \& Arsyianti, L. D. (2016). Ekonomi Pembangunan Syariah (Development Economics from Islamic Perspective). Depok, Indonesia: Raja Grafindo.

Bekkers, R., \& Wiepking, P. (2011). A Literature Review of Empirical Studies of Philanthropy: Eight Mechanisms That Drive Charitable Giving. Nonprofit and Voluntary Sector Quarterly, 40(5), 924-973.

Belsky, E. S., \& Calder, A. (2005). Credit Matters: Building Assets in a Dual Financial Service System. In N. P. Retsinas \& E. S. Belsky (Eds.), Building Assets, Building Credit: Creating Wealth in Low-Income Communities (pp.10-41). Washington: Brookings Institution Press.

al-Bukhari, Muhammad bin Isma'il. (1997). The Translation of the Meanings of Sahīh Al-Bukhāri. Riyadh, KSA: Darussalam.

De Oliveira, A. C. M., Eckel, C. \& Croson, R. T. A. (2012). The Stability of Social Preferences in a LowIncome Neighborhood. Southern Economic Journal, 79(1), 15-45.

DeVaney, S. A. (1994). The Usefulness of Financial Ratios as Predictors of Household Insolvency: Two Perspectives. Financial Counseling and Planning Journal, 5(1), 5-24.

Dhewanthi, L. (2012). Pursuing Sustainable Indonesia: Green Economy Policy Initiatives and Role of Youth [Powerpoint slides]. Retrieved from: http://www. un.org/esa/socdev/egms/docs/2012/greenjobs/sustainab leindonesia.pdf

Driver, M. (2015, April 20). Why financial inclusion is key to ending global poverty [World Economic Forum: Agenda]. Retrieved from: https://agenda.weforum.org/ 2015/04/why-financial-inclusion-is-key-to-endingglobal-poverty/

Garman, E. T., Kim, J., Kratzer, C. Y., Brunson, B. H., \& Joo, S. (1999). Workplace Financial Education Improves Personal Financial Wellness. Financial Counseling and Planning, 10(1), 79-88.

Garman, T., Leech, I., \& Grable, J. (1996). The Negative Impact Of Employee Poor Personal Financial Behaviors On Employers. Association for Financial Counseling and Planning Education, 7, 157-168.

Giesler, M., \& Veresiu, E. (2014). Creating the Responsible Consumer: Moralistic Governance Regimes and Consumer Subjectivity. Journal of Consumer Research, 41(3), 840-857. 
Hafidhuddin, D. (2007). Agar Harta Berkah dan Bertambah (Blessing and Growing Wealth). Jakarta: Gema Insani Press.

Havens, J. J., O’Herlihy, M. A., \& Schervish, P. G. (2006). Charitable giving: How much, by whom, to what, and how? In W. W. Powell, \& R. Steinberg (Eds.), The Nonprofit Sector: A Research Handbook (pp. 542-567). New Haven, CT: Yale University Press.

Hilgert, M. A., \& Hogarth, J. M. (2003). Household Financial Management: The Connection between Know-ledge and Behavior. Federal Reserve Bulletin, 1(July), 309-322.

Hogarth, J. M. (2006, November). Financial Education and Economic Development. Paper prepared for Improving Financial Literacy International Conference hosted by the Russian G8 Presidency in Cooperation with the OECD. Retrieved from: http://www.oecd.org/ finance/financial-education/37742200.pdf

Hogarth, J. M., Beverly, S. G. \& Hilgert, M. (2003, February). Patterns of Financial Behaviors: Implications for Community Educators and Policy Makers. Discussion draft presented at the Federal Reserve System Community Affairs Research Conference. Retrieved from: https:/www. federalreserve.gov/ communityaffairs/national/CA_Conf_SusCommDev/p df/hogarthjeanne.pdf

Hudon, M. (2009). Should access to credit be a right? Journal of Business Ethics, 84(1), 17-28.

Joo, S. (2008). Personal Financial Wellness. In J. J. Xiao, (Ed.), Handbook of Consumer Finance Research (pp. 21-33). New York: Springer Science \& Business Media.

Kendall, J., \& Klapper, L. (2015, May 19). The main facts and figures about financial inclusion around the world [World Economic Forum: Agenda]. Retrieved from: https://agenda.weforum.org/2015/05/the-mainfacts-and-figures-about-financial-inclusion-around-theworld/

Lea, S. E. G., Webley, P., \& Walker, C. M. (1995). Psycho-logical factors in consumer debt: Money management, economic socialization, and credit use. Journal of Economic Psychology, 16(4), 681-701.

Lee, N. R., \& Miller, M. (2012). Influencing positive financial behaviors: the social marketing solution. Journal of Social Marketing, 2(1), 70-86.

Lindenberg, S. (1996). Continuities in the theory of social production functions. In $\mathrm{H}$. Ganzeboom \& $\mathrm{S}$. Lindenberg (Eds.), Verklarende Sociologie: Opstellen voor Reinhard Wippler [Explanatory Sociology: Essays in Honor of Reinhard Wippler] (pp. 169-184). Amsterdam: Thela Thesis Publishers.
Livingstone, S. M., \& Lunt, P. K. (1992). Predicting personal debt and debt repayment: Psychological, social and economic determinants. Journal of Economic Psychology, 13(1), 111-134.

Lusardi, A. (2008). Household saving behavior: the role financial literacy, information and financial education programs (NBER Working Paper No. 13824). Retrieved from: http://www.nber.org/papers/w13824

Lyons, A. C., Chang, Y., \& Scherpf, E. M. (2006). Translating Financial Education into Behavior Change for Low-Income Populations. Journal of Financial Counseling and Planning, 17(2), 27-45.

Mandell, L. \& Klein, L.S. (2009). The Impact of Financial Literacy Education on Subsequent Financial Behavior. Journal of Financial Counseling and Planning, 20(1), 15-24.

Martin, M. (2007). A literature review on the effectiveness of financial education (Federal Reserve Bank of Richmond Working Paper No. 07-03). Retrieved from: https://www.richmondfed.org/ /media/richmondfedorg /publications/research/working_papers/2007/pdf/wp073.pdf .

Mccormick, M. H. (2009). The Effectiveness of Youth Financial Education: A Review of the Literature. Journal of Financial Counseling and Planning, 20(1), 70-83.

McKee-Ryan, F. M., Song, Z., Wanberg, C. R. \& Kinicki, A. J. (2005). Psychological and Physical Well-Being During Unemployment: A Meta-Analytic Study. Journal of Applied Psychology, 90(1), 53-76.

Mewse, A. J., Lea, S. E. G., \& Wrapson, W. (2010). First steps out of debt: Attitudes and social identity as predictors of contact by debtors with creditors. Journal of Economic Psychology, 31(6), 1021-1034.

Morgan, P. J. \& Pontines, V. (2014). Financial Stability and Financial Inclusion (ADBI Working Paper No. 488). Tokyo: Asian Development Bank Institute. Retrieved from: http:/www.adbi.org/working-paper/ 2014/07/07/6353.financial.stability.inclusion/

Muflihani, Z. F. (2015). Faktor-faktor yang Memengaruhi Tingkat Literasi Perbankan Syariah pada Pelaku Usaha Mikro di Kota Bogor (Factors Affecting Islamic Banking Literacy among Micro Entrepreneurs in Bogor City) (Unpublished undergraduate thesis). Bogor Agricultural University, Bogor, Indonesia.

Obaidullah, M. (2008). Introduction to Islamic Microfinance. New Delhi: IBF Net (P) Limited

Organisation for Economic Co-operation and Development. (2006, July). The Importance of Financial Education (Policy Brief). Retrieved from: http://www. oecd.org/finance/financial-education/37087833.pdf 
Ormel, J., Lindenberg, S., Steverink, N., \& Verbrugge, L. M. (1999). Subjective well-being and social production functions. Social Indicators Research, 46, 61-90.

Otoritas Jasa Keuangan (Financial Services Authority). (2011). Act No.21, Law on the Financial Service Authority. Retrieved from: http://www.flevin.com/id/ lgso/translations/Laws/Law\%20No.\%2021\%20of\%20 2011\%20on\%20Financial\%20Service\%20Authority\% 20(MoF).pdf

Otoritas Jasa Keuangan (Financial Services Authority). (2015). OJK-Pedia. Retrieved on September 21st, 2015, from: http://www.ojk.go.id/en/OJK-pedia/ Default.aspx

Pamuk, Ş. (2004a). The evolution of financial institutions in the Ottoman Empire, 1600-1914. Financial History Review, 11(1), 7-32.

Pamuk, Ş. (2004b). Institutional Change and the Longevity of the Ottoman Empire, 1500-1800. The Journal of Interdisciplinary History, 35(2), 225-247.

Plagnol, A. C. (2011). Financial satisfaction over the life course: The influence of assets and liabilities. Journal of Economic Psychology, 32(1), 45-64.

al-Qurtubi, Muhammad bin Admad. (1993). Al-Jami li Ahkam al-Quran. Beirut: Dar al-Kutub al-'Ilmiyyah.

Sahi, S. K. (2013). Demographic and socio-economic determinants of financial satisfaction: A study of SECA segment of individual investors in India. International Journal of Social Economics, 40(2), 127-150.

Schlegelmilch, B. B., Love, A., \& Diamantopoulos, A. (1997). Responses to different charity appeals: the impact of donor characteristics on the amount of donations. European Journal of Marketing, 31(8), 548-560.

Stone, B., \& Maury, R. V. (2006). Indicators of personal financial debt using a multi-disciplinary behavioral model. Journal of Economic Psychology, 27(4), 543-556.

Tambunan, T. (2015). Financial Inclusion, Financial Education, and Financial Regulation: A Story from Indonesia (ADBI Working Paper No. 535). Tokyo: Asian Development Bank Institute. Retrieved from: http://www.adb.org/sites/default/files/publication/1611 76/adbi-wp535.pdf

al-Tirmidhi, Muhammad bin 'Eisa. (2007). English Translation of Jāmi' at-Tirmidhī. Riyadh, KSA: Darussalam.

United Nations. (2015). The Millennium Development Goals Report. New York: United Nations. Retrieved on October 21st, 2015, from http://www.un.org/millen niumgoals/2015 MDG Report/pdf/MDG\%202015\%2 0rev\%20(July\% $\overline{2} 01)$.pdf

Veenhoven, R. (1999). Quality-Of-Life in Individualistic Society: A comparison of 43 nations in the early 1990’s. Social Indicators Research, 48, 157-186.
Willis, L. E. (2011). The Financial Education Fallacy. American Economic Review, 101(3), 429-434.

Winters, M. S., \& Rundlett, A. (2015). The Challenges of Untangling the Relationship Between Participation and Happiness. VOLUNTAS: International Journal of Voluntary and Nonprofit Organizations, 26(1), 5-23.

World Bank. (2014). Infographic: Global Findex 2014 Gender and Income. Retrieved on October 8th, 2015, from: http://www.worldbank.org/en/programs/global findex/infographics/infographic-global-findex-2014gender-income

World Bank. (2016a). Financial Inclusion: Overview. Retrieved on May 24th, 2016, from: http://www.world bank.org/en/topic/financialinclusion

World Bank. (2016b). Overview: National Financial Inclusion Strategies. Retrieved on May 24th, 2016, from: http://www.worldbank.org/en/topic/financialin clusion/brief/national-financial-inclusion-strategies

World Bank. (2016c). UFA2020 Overview: Universal Financial Access by 2020. Retrieved on May 24th, 2016, from: http://www.worldbank.org/en/topic/ financialinclusion/brief/achieving-universal-financialaccess-by-2020

Wright, K. (2001). Generosity vs . Altruism: Philanthropy and Charity in the United States and United Kingdom. Voluntas: International Journal of Voluntary and Nonprofit Organizations, 12(4), 399-416.

Xiao, J. J., \& Wu, J. (2008). Completing Debt Management Plans in Credit Counseling: An Application of the Theory of Planned Behavior. Journal of Financial Counseling and Planning, 19(2), 29-45.

Xiao, J. J., \& Yao, R. (2014). Consumer debt delinquency by family lifecycle categories. International Journal of Bank Marketing, 32(1), 43-59.

Yayasan Dompet Dhuafa Republika. (2013). Financial Statements for the year ended December 31, 2013 with Independent Auditors' Report.

Yumna, A. \& Clarke, M. (2011, December). Integrating zakat and Islamic charities with microfinance initiative in the purpose of poverty alleviation in Indonesia. Paper presented at the 8th International Conference on Islamic Economics and Finance, Doha, Qatar. Retrieved from: http:/www.assaif.org/ara/content/ download/33273/178973/file/Zakat\%20an\%20Islamic \%20Microfinance.pdf

Zhan, M., Anderson, S. G., \& Scott, J. (2006). Financial knowledge of the low-income population: Effects of a financial education program. Journal of Sociology and Social Welfare, 33(1), 53-74.

Zhu, L. Y., \& Meeks, C. B. (1994). Effects of Low Income Families' Ability and Willingness to Use Consumer Credit on Subsequent Outstanding Credit Balances. The Journal of Consumer Affairs, 28(2), 403422 . 
Laily Dwi Arsyianti is currently a PhD candidate at the IIUM Institute of Islamic Banking and Finance, International Islamic University Malaysia (IIUM). She graduated from the same institution to earn her Master of Science in Finance degree, and Bogor Agricultural University (Institut Pertanian Bogor, or IPB), Indonesia for her Bachelor degree. She is attached with her under-graduate institution in the Department of Islamic Economics, Faculty of Economics and Management (FEM). Her research interests include Islamic banking and finance and behavioral finance. She has published some of her research in refereed academic journals and earned grants to present in several conferences.

E-mail: arsyianti@apps.ipb.ac.id

Salina Kassim is currently Associate Professor at the IIUM Institute of Islamic Banking and Finance, International Islamic University Malaysia (IIUM). Prior to becoming an academician, she has several years of working experience in a commercial bank in Malaysia. She teaches Money and Banking, and Islamic Banking and Finance at the under-graduate level, and Islamic Financial Systems, Financial Economics and Contemporary Issues in Islamic Finance at the graduate level. Her research interests include Islamic banking and finance, and monetary/financial economics. She has published extensively in refereed academic journals in her areas of research interest. She also sits on the editorial boards of several reputable international journals. She earned her $\mathrm{PhD}$ in Monetary Economics in 2006 from the IIUM and her Masters and Bachelor degrees from the USA in 1992 and 1994, respectively.

E-mail:ksalina@iium.edu.my 


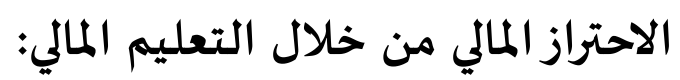

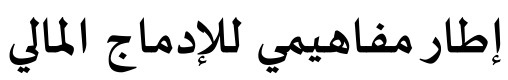

\author{
ليلى دوي عرشيانتي \\ محاضر، جامعة بوجور الزراعية، إندونيسيا \\ سالينة قاسم
}

أستاذ مشارك، معهلد المصرفية الإنلامية والتمويل، الجامعة الإسلامية العالمية، ماليزيا

المستخلص. تهدف هذه الورقة إلى رسم إطار لتحسين الحكمة المالية من خلال التعليم المالي

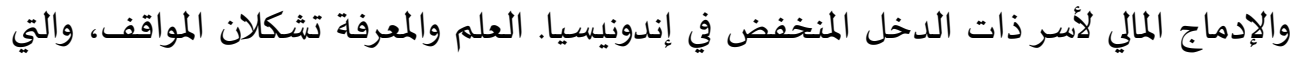

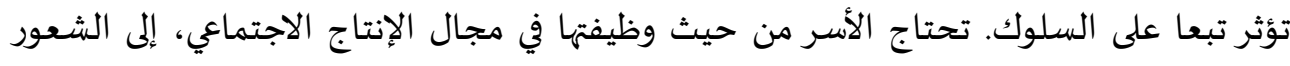

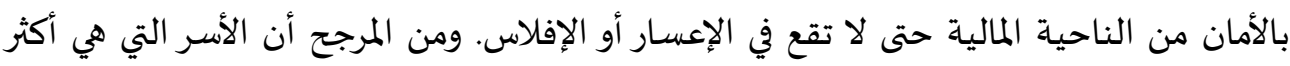

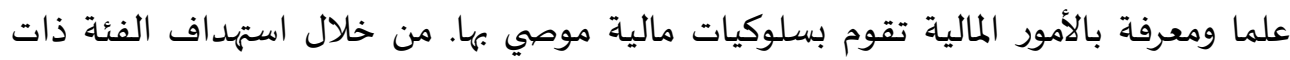

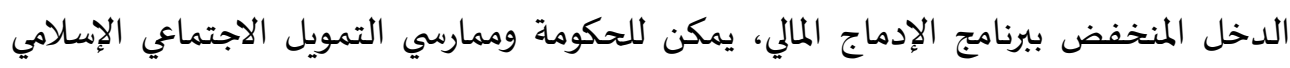

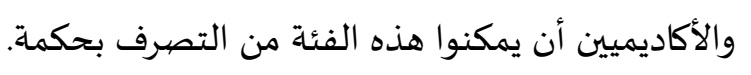
الكلمات الرئيسية: السلوك المالي، الإدماج المالي، التعليم المالي، الأسر ذات الدخل المنخفض. 